\title{
The Disciplinary and Criminal Liability of Judges in Poland. A Criminalistics Study of Cases of Disciplinary and Criminal Liability of Judges in the Years 2010-2018
}

\section{Introduction}

The article presents basics findings about the disciplinary and criminal liability of the judges of common courts in Poland. ${ }^{1}$ These findings are presented from a criminalistics perspective. Inspiration for the paper was the recent public debate in Poland on the state of the judiciary and the reform in 2019 regarding the disciplinary liability of judges. ${ }^{2}$

1 Common courts in Poland are district courts, regional courts and courts of appeal. See art. 1 $\S 1$ of Act of 27 July 2001 Law on the System of Common Courts. Journal of Laws of 2020, item 365. Hereinafter: LSCC.

2 This debate concerned a change in the model of the disciplinary liability of judges. By the Act of December 8, 2017 on the Supreme Court, among others, a disciplinary chamber was established. The establishment of this chamber aroused controversy in many legal circles and was considered by the Court of Justice of the European Union (see case C-791/19 - Commission v. Poland (Régime disciplinaire des juges)). It also contributed to the adoption of a resolution by the combined chambers of the Supreme Court, i.e. the Civil, Criminal, Labor and Social Insurance Chamber on January 23, 2020, file ref. BSA I-4110-1 / 20 <http://www.sn.pl/sites/orzecznictwo/orzeczenia2/bsa\%20i-4110-1-20.pdf>, stating that decisions issued under the participation of the judges of the Disciplinary Chamber established in the Supreme Court pursuant to the Act of December 8, 2017 on the Supreme Court (Journal of Laws of 2018, item 5, as amended), regardless of the date of issuance of these judgments, are subject to the sanction of nullity of the proceedings. In connection with this ruling, by the resolution of April 10, 2019 (reference number II DSI 54/18), the Disciplinary Chamber of the Supreme Court in full court indicated that the participation in the court of a person who was appointed by the President of the Republic of Poland to hold the office of a Supreme Court judge [...] does not infringe upon the provisions of art. 6 sec. 1 of the Convention for the Protection of Human Rights and Fundamental Freedoms (Jour- 
The article provides data on the following issues: the basics of the disciplinary and criminal liability of judges, the number of disciplinary cases of judges in the years 2010-2018 and the number of criminal cases of judges in the years 2001-2017, categories of the disciplinary violations and crimes committed, decisions taken in cases involving disciplinary violations, and the imposed penalties. The article is based on an examination of Supreme Court verdicts issued in disciplinary cases of judges and data provided by the Ministry of Justice. ${ }^{3}$

A recent public debate in Poland concerns the disciplinary liability of judges and mistakes made by courts in the judgments issued. It would be worth conducting such a debate regarding the professional liability of other legal professions, i.e. prosecutors, lawyers, legal advisers, notaries and bailiffs. It is hoped that this article will initiate further discussion about these issues among scientists, practitioners and the general public. In the preparation of the article the research on the disciplinary liability of lawyers carried out in other countries of the European Union, and the results of this research, were taken into consideration. ${ }^{4}$

nal of Laws of 1993, No. 61, item 284), the right to have a case heard by an independent and impartial court established by law, as a result of which such a person is not an unauthorized person, and the composition adjudication of the court in which such a person sits is not a court properly filled, <http://www.sn.pl/orzecznictwo/SitePages/Najnowsze_orzeczenia. aspx?ItemSID=1218-301f4741-66aa-4980-b9fa-873e90506a11\&ListName=Zagadnien ia_prawne $>$. This compilation is a study from a criminalistics point of view, and therefore the discussion of the above-mentioned political debate was intentionally omitted from it.

3 See Ł. Piebiak, Odpowiedź na interpelację nr 25389 w sprawie postępowań karnych wobec sędziów, <http://www.sejm.gov.pl/sejm8.nsf/InterpelacjaTresc.xsp?key=B4SHUE>.

4 See CEPEJ Report on European judicial systems -Edition 2014 (2012 data): efficiency and quality of justice, <http://www.just.ro/wp-content/uploads/2015/09/editia-2014-en. pdf>, p. 354. Cf. E. Gruodytè, The disciplinary liability of Lithuanian Lawyers: a comparative approach, "Baltic Journal of Law \& Politics" 2014, no. 2, pp. 1-36; A. Tsaoussi, E. Zervogianni, Judges as satisficers: a law and economics perspective on judicial liability, "European Journal of Law and Economics” 2010, no 29, pp. 333-357; Minimum Judicial Standards V, Disciplinary proceedings and liability of judges, ENCJ Report 2014-2015, $<$ https://www.encj.eu/images/stories/pdf/GA/Hague/encj_report_minimum_standards_v_ adopted_ga_june_2015.pdf >; N. Acquaviva, F. Castagnet, M. Evanghelou, A comparative analysis of Disciplinary Systems for European judges and prosecutors, For the 7th edition of the THEMIS Competition - 2012, <http://www.ejtn.eu/Documents/Themis\%202012/ THEMIS\%202012\%20ERFURT\%20DOCUMENT/Written\%20paper\%20France\%203.pdf >. 


\section{The Basic Issues Associated}

\section{with the Disciplinary and Criminal Liability of Judges}

The framework for the functioning of judges in Poland is determined by the Constitution of the Republic of Poland, which indicates that judges, when exercising their office, are independent and subject only to the Constitution and statutes. ${ }^{5}$ However, under the terms regulated by the Constitution and statutes, judges are subject to disciplinary and criminal liability.

The legal grounds for the disciplinary liability of judges are regulated by the Act of 27 July 2001 Law on the System of Common Courts (LSCC). The principles of this liability are governed by the provisions of Art. 107-133a LSCC.

In the current legal situation, the judge is disciplinarily responsible for official (disciplinary) offenses, including:

1) an obvious and blatant insult to the law

2) acts or omissions that may prevent or significantly impede the functioning of the judicial authority

3) actions questioning the existence of a judge's service relationship, the effectiveness of the appointment of a judge, or the empowerment of the constitutional body of the Republic of Poland

4) public activities incompatible with the principles of the independence of courts and judges

5) a breach of the dignity of the office.

These grounds for the disciplinary liability of judges have been applicable since February 14, 2020, when the legislator amended art. $107 \S 1$ LSCC. Until February 13, 2020, judges were disciplinarily responsible for misconduct, including an obvious and blatant offense against the law and the dignity of the office. The scope of the acts subject to this responsibility was therefore narrower. ${ }^{6}$

5 See art 178 § 1 Constitution of the Republic of Poland of April 2, 1997 (Journal of Law of 1997, no. 07, item 15). Hereinafter: Constitution.

6 The amendment of 20 December 2019 - the Act amending the Act - Law on the System of Common Courts, the Act on the Supreme Court and some other acts (Journal of Law 
The LSCC Act also specifies the scope of duties of judges, non-compliance with which also provides grounds for disciplinary liability. These obligations are: the obligation to improve professional qualifications, the obligation of patronage over the conduct of trainee judges, the obligation to perform activities in relation to the duties entrusted to the disciplinary court judge, the obligation to maintain professional secrecy, a prohibition on taking additional employment except for teaching or academic positions, and a prohibition on occupying positions specified in the Act, the obligation to submit a property declaration, the obligation to submit a declaration of membership in associations, performing functions in foundation bodies, membership in a political party, the obligation to follow the official route in matters related to the office held, the obligation to notify about a pending court case in which the judge acts as a party or a participant, and the obligation to reside in the city being the seat of the court. $^{7}$ The judge should obtain the consent of the president of the superior court or of the court of residence to employment in the didactic or scientific position, and for residing outside the place of service. Failure to obtain this consent also provides grounds for disciplinary liability.

The grounds for the material liability of judges for disciplinary offenses are also specified in the Code of Ethics for Judges, as set out in the resolution of the National Council of the Judiciary. The Code of Ethics for Judges is also applied to retired judges and court assessors. These rules set standards for the conduct of a judge during and outside the service. The rules of ethics impose on the judge, among other things, the obligation to take actions without undue delay, to maintain an appropriate attitude towards the parties to the proceedings, to maintain neutrality towards the parties in the course of the proceedings, to take care of proper organi-

of 2020, item 190). Cf. W. Kozielewicz, Odpowiedzialność dyscyplinarna sędziów, in: Odpowiedzialność dyscyplinarna sędziów, prokuratorów, radców prawnych i notariuszy, ed. W. Kozielewicz, Warszawa 2016, pp. 128-192; J. Sawiński, Commentary on Article 107 LSCC, in: Law on the System of Common Courts. Commentary, ed. A. Górski, Lex 2013.

7 The principles of disciplinary liability of judges are similarly shaped in other European Union countries, for example in Lithuania. See E. Gruodytè, The disciplinary liability of Lithuanian Lawyers..., p. 21. 
zation of work, to refrain from relations and behaviour in the course of performing their duties and outside of them which could undermine the prestige of the office of the judge and reduce confidence in the judge, and to demonstrate integrity in their own financial matters and prudence in social life. ${ }^{8}$ In addition, a judge cannot belong to a political party or trade union, or conduct public activities incompatible with the principles of the independence of the courts and the independence of judges. ${ }^{9}$

The judge is also disciplinarily responsible for their conduct before taking up the position, if they have failed to fulfill their duty as a state office at the time or proved to be unworthy of the office of a judge. ${ }^{10}$ The court assessor's disciplinary liability is based on the same principle as the disciplinary liability of judges. ${ }^{11}$

A retired judge is also obliged to maintain the dignity of a judge. A retired judge is disciplinarily liable for a breach of the dignity of a judge after retirement and a breach of the dignity of a judge's office during their service. ${ }^{12}$

Disciplinary proceedings are two-instance. The disciplinary court of the first instance is the court of appeal in the district of which the judge performs their duties. The Supreme Court is the second instance disciplinary court. ${ }^{13}$ Exceptionally, after the amendment of the LSCC from April 3, 2018, the Supreme Court acts as the first instance court in disciplinary offenses that exhaust the features of intentional offenses prosecuted by public prosecution or intentional fiscal offenses, or cases in which the judge was accused of committing an offense involving questioning the existence of a judge's service relationship, the effectiveness of the appointment of

8 See Resolution no. 25/2017 of The National Council of the Judiciary of January 13, 2017 regarding the publication of a consolidated text of the Set of Professional Ethics Rules for Judges and Court Assessors, <https://krs.pl/pl/o-radzie/zbior-zasad-etyki-zawodowej-sedziow/591uchwala-nr-25-2017-krajowej-rady-sadownictwa-z-dnia-13-stycznia-2017-r.html>.

9 See art. $178 \S 3$ of the Constitution.

10 See art. $107 \S 1$ LSCC.

11 See art. 107a LSCC.

12 See art. $104 \S 1$ and 2 LSCC.

13 See art. 110 LSCC. 
a judge, or the empowerment of the constitutional body of the Republic of Poland. ${ }^{14}$ Prosecutors before the disciplinary court are the Disciplinary Spokesman for the Judges of the Common Courts and the Deputy Disciplinary Spokesman for the Judges of the Common Courts, as well as the deputy disciplinary spokesperson operating at the courts of appeal and the deputy disciplinary spokesperson operating at the regional courts. The Disciplinary Spokesman for the Judges of the Common Courts and two Deputy Disciplinary Spokesmen for the Judges of the Common Courts are appointed by the Minister of Justice for a four-year term. ${ }^{15}$

During the disciplinary proceedings, the accused may appoint a defence counsel from among judges, prosecutors, attorneys or legal counsels. ${ }^{16}$

The disciplinary liability of a judge is independent of any criminal liability. Disciplinary proceedings are conducted regardless of criminal proceedings, also in the event of the simultaneous and subject-related identity of these proceedings. ${ }^{17} \mathrm{~A}$ judge may not be held criminally responsible or deprived of liberty without the prior consent of the relevant disciplinary court. The permission to prosecute a judge is issued by the Supreme Court and is expressed in the form of a resolution. ${ }^{18}$ The disciplinary court issues a resolution allowing a judge to be held criminally liable if there is a sufficiently justified suspicion that they have committed a crime. ${ }^{19}$ Without the consent of the Supreme Court, the judge is liable only to disciplinary action. The judge may, however, agree to be held criminally responsible for road safety offenses (e.g. causing a threat to road safety, driving a vehicle under the influence of alcohol or speeding). In this case, the ability to hold a judge to disciplinary liability is excluded. ${ }^{20}$

14 See art. $110 \S 1$ item 1 letter b LSCC.

15 See art. $112 \S 1$ and 3 LSCC.

16 See art. $113 \S 1$ LSCC.

17 See Supreme Court resolution of September 28, 2006, reference number I KZP 8/06.

18 See art. $80 \S 1$ and 119 LSCC and art. 181 of the Constitution.

19 See art. 80 § 2c LSCC.

20 See art. 81 LSCC. Cf. W. Kozielewicz, Odpowiedzialność dyscyplinarna sędziego za wykroczenie, in: Państwo prawa i prawo karne. Księga jubileuszowa Profesora Andrzeja Zolla, 


\section{The Number of Disciplinary Violations}

According to the European Commission for the Efficiency of Justice ${ }^{21}$ Report, the number of disciplinary proceedings initiated per 100 judges in 2012 in Poland is lower than average, and Poland takes the 25th place in this report. Poland achieved a result of 0.5 point in this respect. The same as Romania and only 0.1 point more than Estonia, Hungary, Serbia, Montenegro and Bulgaria. The highest ratio was achieved by the UK - England and Wales, Norway, Republic of Moldova, Iceland and Lithuania (from 55.3 points to 7.8 ). ${ }^{22}$ The above indicates that the number of disciplinary proceedings in Poland is lower than in other European Union countries. The number of disciplinary cases of judges decided by the Supreme Court in the period from 2001 to 2019 is presented in Table 1.

As can be seen in Table 1, the number of cases decided by the Supreme Court in individual years varies between 9 and 59, with the average number of cases considered annually by the Supreme Court being 35. Taking into consideration the statistical data presented by CEPEJ and concerning other countries, this is not a significant number. However, it is certainly desirable for the number of disciplinary cases for judges, and hence the number of disciplinary offenses, to be kept at a minimum. At the same time, in most cases during the period considered, the accused were guilty of disciplinary offenses. Data on this subject are presented in Table 2.

ed. P. Kardas, vol. 2, Lex.

21 Hereinafter: CEPEJ. It is worth noting that the aim of the CEPEJ is the improvement of the efficiency and functioning of justice in the member States, and the implementation of the instruments adopted by the Council of Europe to this end. To carry out these tasks, the CEPEJ prepares benchmarks, collects and analyses data, defines instruments of measure and means of evaluation, adopts documents (reports, advice, guidelines, action plans, etc.), develops contacts with qualified personalities, non-governmental organizations, research institutes and information centres, organizes hearings, promotes networks of legal professionals. Its tasks, among others, are to analyse the results of the judicial systems and to identify the difficulties they meet. The result of these works are annual reports on the functioning of the justice system in individual countries of the European Union. Vid. About the European Commission for the efficiency of justice (CEPEJ), <https://www.coe.int/en/web/cepej/about-cepej>.

22 See CEPEJ Report on European judicial systems -Edition 2014 (2012 data): efficiency and quality of justice, <http://www.just.ro/wp-content/uploads/2015/09/editia-2014-en.pdf, p. 354>. 
Table 1. The number of disciplinary cases of judges decided by the Supreme Court in the period from 2001 to 2019

\begin{tabular}{|c|c|c|}
\hline No. & Year & $\begin{array}{c}\text { Number of } \\
\text { cases }\end{array}$ \\
\hline 1. & 2002 & 11 \\
\hline 2. & 2003 & 47 \\
\hline 3. & 2004 & 28 \\
\hline 4. & 2005 & 36 \\
\hline 5. & 2006 & 47 \\
\hline 6. & 2007 & 59 \\
\hline 7. & 2008 & 49 \\
\hline 8. & 2009 & 55 \\
\hline 9. & 2010 & 30 \\
\hline 10. & 2011 & 28 \\
\hline 11. & 2012 & 20 \\
\hline 12. & 2013 & 24 \\
\hline 13. & 2014 & 44 \\
\hline 14. & 2015 & 47 \\
\hline 15. & 2016 & 39 \\
\hline 16. & 2017 & 31 \\
\hline 17. & 2018 & 4 \\
\hline 18. & 2019 & 15 \\
\hline & & \\
\hline
\end{tabular}

The data in Table 2 demonstrate that the courts of first instance usually recognized the merits of the accusation against the judge. Occasionally, however, the judge was acquitted of committing the offense of which they were accused. Incidentally, acquittals by the second instance court (the Supreme Court) were also imposed. 
The Disciplinary and Criminal Liability of Judges in Poland... | 299

Table 2. The number of convictions in the period 2010-2019

\begin{tabular}{|c|c|c|c|c|c|c|c|}
\hline \multirow[b]{2}{*}{ No. } & \multirow[b]{2}{*}{ Year } & \multicolumn{4}{|c|}{ First instance } & \multirow[b]{2}{*}{ Total } & \multirow{2}{*}{$\begin{array}{c}\begin{array}{c}\text { Second instance } \\
\text { (Supreme Court) }\end{array} \\
\text { Acquittals* }\end{array}$} \\
\hline & & ن & 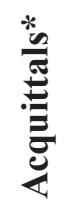 & 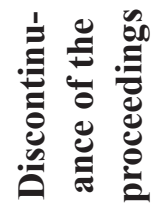 & 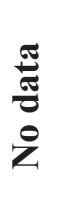 & & \\
\hline 1. & 2010 & 27 & 3 & 3 & 0 & 33 & 3 \\
\hline 2. & 2011 & 25 & 3 & 8 & 0 & 36 & 2 \\
\hline 3. & 2012 & 20 & 6 & 1 & 0 & 27 & 0 \\
\hline 4. & 2013 & 24 & 5 & 1 & 0 & 30 & 1 \\
\hline 5. & 2014 & 39 & 10 & 5 & 0 & 54 & 6 \\
\hline 6. & 2015 & 45 & 15 & 4 & 0 & 64 & 3 \\
\hline 7. & 2016 & 35 & 7 & 2 & 0 & 44 & 3 \\
\hline 8. & 2017 & 27 & 3 & 4 & 0 & 34 & 1 \\
\hline 9. & 2018 & 5 & 0 & 0 & 0 & 5 & 0 \\
\hline 10. & 2019 & 11 & 5 & 1 & 3 & 20 & 0 \\
\hline \multicolumn{2}{|c|}{ Total } & 258 & 57 & 29 & 3 & - & 23 \\
\hline
\end{tabular}

* Regarding the acts specified in the case.

\section{Categories of Disciplinary Violations}

Disciplinary offenses most often concerned district court judges; less often regional court judges. The cases where the judge of the appeal court acted as the accused occurred occasionally. This structure of the perpetrators should be unsurprising, as most courts in Poland are district courts. ${ }^{23}$ In most of the examined cases, the accused were judges still in office. The cases of prosecution of retired judges have occurred infre-

23 There are 318 district courts, 45 regional courts, and 11 appeal courts in Poland. See Lista sq̨dów powszechnych, <https://dane.gov.pl/dataset/985,lista-sadow-powszechnych/ resource/3873/table?page=3\&per_page=20\&q=\&sort=>. 
quently. ${ }^{24}$ Table 3 presents the characteristics of the accused persons in the examined cases.

Table 3. The characteristics of the accused persons in the examined cases

\begin{tabular}{|c|c|c|c|c|c|c|c|c|}
\hline \multirow[b]{2}{*}{ No. } & \multirow[b]{2}{*}{ Year } & \multicolumn{4}{|c|}{ Judges* } & \multirow[b]{2}{*}{ Total } & \multirow[b]{2}{*}{$\begin{array}{c}\text { Retired } \\
\text { judges** }\end{array}$} & \multirow[b]{2}{*}{ No data } \\
\hline & & 泀 & 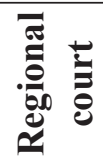 & 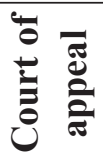 & $\begin{array}{l}\text { 苞 } \\
\text { है } \\
\text { ż }\end{array}$ & & & \\
\hline 1. & 2010 & 25 & 6 & 0 & 0 & 31 & 1 & 0 \\
\hline 2. & 2011 & 20 & 9 & 0 & 0 & 29 & 2 & 0 \\
\hline 3. & 2012 & 12 & 7 & 1 & 0 & 20 & 2 & 0 \\
\hline 4. & 2013 & 19 & 6 & 0 & 0 & 25 & 1 & 0 \\
\hline 5. & 2014 & 34 & 10 & 0 & 0 & 44 & 3 & 0 \\
\hline 6. & 2015 & 34 & 12 & 2 & 0 & 48 & 4 & 0 \\
\hline 7. & 2016 & 31 & 8 & 0 & 0 & 39 & 5 & 0 \\
\hline 8. & 2017 & 24 & 7 & 2 & 0 & 33 & 5 & 0 \\
\hline 9. & 2018 & 3 & 1 & 0 & 0 & 4 & 1 & 0 \\
\hline 10. & 2019 & 8 & 3 & 1 & 3 & 14 & 3 & 3 \\
\hline \multicolumn{2}{|c|}{ Total } & 210 & 69 & 6 & 3 & - & 27 & 3 \\
\hline
\end{tabular}

* The number of judges accused in the examined cases is not equal to the number of cases, as it happened that in one case there were two or three accused.

** The number of retired judges covers district, regional, and appeal court judges.

As Table 3 shows, most of the defendants in the examined cases were judges of district courts. Nevertheless, the number of accused regional court judges accounted for almost $1 / 3$ of the number of accused district court judges. The above indicates that the disciplinary offenses apply equally to the district and regional courts.

The analysis of the types of disciplinary offenses of the accused judges in the examined cases suggests that the most frequently alleged offense

24 The institution of the court assessor did not function in the audited period, therefore no accusations were recorded among this group. 
was causing proceedings to be excessive in length and preparing justifications for rulings issued that exceeded the deadline. Exceeding the deadline usually meant a few or several additional weeks. There were, however, cases of dozens of weeks of delay. ${ }^{25}$ The results of the conducted research also indicate that in most cases the accusation of conducting excessively lengthy proceedings concerned judges of district courts. Disciplinary offenses related to the excessive length of proceedings were qualified by the disciplinary court as an obvious and blatant offense against the law. A detailed list of the types of offenses alleged against the accused persons is presented in Table 4.

Table 4. The types of offenses alleged against the accused persons

\begin{tabular}{|c|c|c|c|c|c|c|c|c|c|c|c|c|}
\hline \multirow[b]{2}{*}{ No. } & \multirow[b]{2}{*}{ Type of offense } & \multicolumn{10}{|c|}{ Number of cases* } & \multirow{2}{*}{ 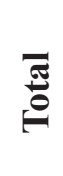 } \\
\hline & & 육 & $\bar{\nexists}$ & ָั) & 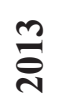 & $\underset{\sim}{\stackrel{\sim}{*}}$ & 需 & 穴 & $\frac{1}{2}$ & $\stackrel{\infty}{\frac{\text { ก }}{1}}$ & 록 & \\
\hline 1. & $\begin{array}{l}\text { Obvious and } \\
\text { blatant offense } \\
\text { against the law }\end{array}$ & 15 & 21 & 10 & 15 & 29 & 34 & 24 & 15 & 1 & 7 & 171 \\
\hline 2. & $\begin{array}{l}\text { Compromising } \\
\text { the office's } \\
\text { dignity }\end{array}$ & 14 & 9 & 11 & 10 & 16 & 17 & 21 & 16 & 3 & 6 & 123 \\
\hline 3. & $\begin{array}{l}\text { Other disciplin- } \\
\text { ary offenses }\end{array}$ & 1 & 1 & 0 & 1 & 1 & 1 & 1 & 1 & 0 & 0 & 7 \\
\hline 4. & No data & 1 & 0 & 0 & 1 & 0 & 0 & 0 & 0 & 0 & 3 & 2 \\
\hline & Total & 31 & 31 & 21 & 27 & 46 & 51 & 46 & 32 & 4 & 16 & - \\
\hline
\end{tabular}

* The number of alleged offenses is not always consistent with the number of examined cases, because it often happened that the accused was charged with more than one act, and it also happened that one act fulfilled the features of two disciplinary offenses.

25 For example, in case reference number SNO 10/16, the excessive length of the proceedings conducted by the accused concerned 1060 cases, while in case reference number SNO 31/12 the lengthy drafting of the justification of the rulings took 191 days, 159 days, 132 days, etc. 
As can be seen from the data contained in Table 4, most acts committed by the accused, although not in all years, are acts of obvious and blatant offense against the law. As indicated above, most of these acts concern slowness in action and causing an excessive length of proceedings or drafting justifications of rulings issued after the statutory deadline. In this group of acts, however, there were cases of other infringements of law. For example, in case reference number SNO 41/11, the chairman of the court department was accused of forming a non-compliant adjudication panel. These cases also include cases of failure by the accused to obtain the required consent of the president of the court for additional professional activity ${ }^{26}$ or faulty proceedings in pending cases. ${ }^{27}$

Part of the cases in which the judges were accused of breaching the dignity of the profession of a judge were those in which the accused was charged with committing a crime. As indicated above, committing a crime by a judge entails not only criminal liability, but also, regardless of this, disciplinary action. However, most of these acts concerned torts that did not qualify for crime but did not reflect well on the seriousness of the judge's profession. The behaviour of these judges' is illustrated by examples 1-9.

\section{Example 1}

The judge was accused of breaching the dignity of the judge's profession, manifested in improper behaviour in neighbourly relations, in particular the use of profanity to a neighbour, repeatedly interfering with the neighbour's property, parking a car with its back to the neighbouring property and emitting exhaust gases, and smoking at the entrance. ${ }^{28}$

\section{Example 2}

The judge was charged with the obligation to pay maintenance to her husband to avoid property execution. ${ }^{29}$

26 For example, in case reference number SNO 23/14, SNO 16/15, SNO 31/16.

27 For example, in case SNO 21/16, SNO 65/15, SNO 59/15, SNO 45/15.

28 See SNO 34/15.

29 See SNO 9/15, SNO 66/15. 


\section{Example 3}

The judge was accused of exceeding the legal speed limit by $49 \mathrm{~km} / \mathrm{h}$ and dismissing a police officer in an arrogant and rude way. ${ }^{30}$

\section{Example 4}

The judge was accused of urging the parties to the proceedings to withdraw their complaint about its length. ${ }^{31}$

\section{Example 5}

The judge was accused of failing to follow the instructions of a security guard when entering the stadium to participate in a football match, concerning the prohibition on people under the influence of alcohol entering the stadium, and of using vulgar phrases. ${ }^{32}$

\section{Example 6}

The judge was accused of inappropriate behaviour towards the inspector assessing his achievements during proceedings regarding promotion to a higher court. ${ }^{33}$

\section{Example 7}

The judge was accused of driving a car under the influence of alcohol. ${ }^{34}$

\section{Example 8}

The judge was accused of forging the signature on an invoice, in the place of the person authorized to collect it. ${ }^{35}$ 


\section{Example 9}

The judge was accused of confirming a falsehood in a hearing report, by indicating that at the hearing on a given day a verdict was passed, while it was not. ${ }^{36}$

The above examples show that this group of offenses concerns both the relations of the judge with other judges, including superiors and colleagues, but also concerns parties to the trial, as well as relations established by the judges with persons from their non-professional environment. This structure of offenses is compatible with the judge's code of ethics, which indicate that both in professional and private life, the judge should behave in a dignified manner, as befits a judge.

\section{Decisions Taken in Cases of Disciplinary Violations and Penalties Imposed}

In the Polish legal system disciplinary penalties are:

1) a warning

2) a reprimand

3) a reduction of basic salary by $5 \%-50 \%$ for a period of six months to two years

4) a financial penalty

5) removal from the function held

6) transfer to another place of service

7) dismissal of the judge from the office. ${ }^{37}$

36 See SNO 7/16.

37 Art. 109 § 1 LSCC. In principle, these penalties coincide with those used in other European legal systems. Vid. N. Acquaviva, F. Castagnet, M. Evanghelou, A comparative analysis of Disciplinary Systems..., p. 14. 
For disciplinary offenses specified in items $2-4^{38}$, the penalty that is imposed is a transfer to another place of service or dismissal of the judge from the office. In cases of less significance, the penalty that may be imposed is the reduction of basic salary, a financial penalty, or removal from the function held. These principles of imposing penalties in relation to the identified acts have been in force since February 14, 2020.39

The penalty of transferal to another place of service consists of changing the official place of the judge to that in:

1) a district court in another appeal area - in the case of a district court judge,

2) a regional court in another appeal area - in the case of a regional court judge,

3) another court of appeal - in the case of a court of appeal judge.

The location of the court is specified in the disciplinary court judgment. In exceptional cases, it is possible to transfer a judge to another place of service in the district of the same appeal in which the court, being the place of the previous adjudication of the judge, is located. ${ }^{40} \mathrm{~A}$ judge who has been adjudicated the penalty of dismissal from the office cannot apply for this office again ${ }^{41}$. The disciplinary court may waive the imposition of a penalty in the event of disciplinary misconduct or a minor offense. $^{42}$

A final conviction of a disciplinary court is to be made public. The disciplinary court may refrain from making the judgment public if it is unnecessary to achieve the purposes of disciplinary proceedings or

38 Which are acts or omissions that may prevent or significantly impede the functioning of the judicial authority; actions questioning the existence of a judge's service relationship, the effectiveness of the appointment of a judge, or the empowerment of the constitutional body of the Republic of Poland; public activities incompatible with the principles of the independence of courts and judges.

39 See art. 109 § 1a LSCC.

40 See art. 109 § 3a-3c LSCC.

41 See art. 109 § 4 LSCC.

42 See art. $109 \S 5$ LSCC. 
to protect legitimate private interests. A final acquittal of a disciplinary court shall be made public at the request of the accused judge. The judgment of the disciplinary court is made public by it being posted on the Supreme Court website. ${ }^{43}$

The disciplinary court may impose the following penalties on a retired judge:

1) a warning,

2) a reprimand,

3) a reduction of salary by $5 \%-50 \%$ for a period of six months to two years,

4) suspension of the salary increase referred to in art. $100 \S 3$, for a period of one to three years,

5) deprivation of the right to retirement with the right to emolument. ${ }^{44}$

Almost all these types of penalties were imposed in the examined cases by the disciplinary court. The most frequently imposed penalties were warnings and reprimands; however, the dismissals of a judge from the office were also often ordered. ${ }^{45}$ Tables 5-7 present a list of penalties imposed on the accused by the first and second instance courts.

43 See art. 109a LSCC.

44 See art. 104 § 3 LSCC.

45 These findings are partly consistent with the results regarding disciplinary proceedings of judges carried out in Lithuania. Lithuania, as indicated above, is at the forefront of European countries with the highest number of disciplinary proceedings against judges. At the same time, and this is worth emphasizing, in that country, there is a relatively small number of cases where a judge is removed from office. In the years 2003-2012, this penalty was applied by the Lithuanian disciplinary court only once, in relation to a judge who in his public speeches used improper language, expressed contempt for other members of society, and aimed to discredit his colleagues and the authority of the court. See E. Gruodytè, The disciplinary liability of Lithuanian Lawyers..., p. 26. 
Table 5. Types of penalties imposed - rulings of the first instance disciplinary court

\begin{tabular}{|c|c|c|c|c|c|c|c|c|c|c|c|c|}
\hline \multirow[b]{2}{*}{ No. } & \multirow[b]{2}{*}{$\begin{array}{l}\text { Type of } \\
\text { penalty }\end{array}$} & \multicolumn{10}{|c|}{ Number of cases } & \multirow[b]{2}{*}{ Total } \\
\hline & & 을 & $\bar{乛}$ & 류 & 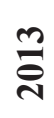 & ন্ & $\stackrel{n}{\frac{n}{2}}$ & 률 & 흘 & $\stackrel{\infty}{\stackrel{\sim}{2}}$ & बे & \\
\hline 1. & Warning & 9 & 7 & 2 & 8 & 16 & 17 & 17 & 7 & 1 & 1 & 85 \\
\hline 2. & Reprimand & 9 & 6 & 10 & 7 & 11 & 10 & 5 & 6 & 1 & 1 & 66 \\
\hline 3. & $\begin{array}{l}\text { Reduction } \\
\text { of salary }\end{array}$ & 0 & 0 & 0 & 1 & 2 & 2 & 1 & 3 & 1 & 2 & 12 \\
\hline 4. & $\begin{array}{l}\text { Financial } \\
\text { penalty }\end{array}$ & 0 & 0 & 0 & 0 & 0 & 0 & 0 & 0 & 0 & 0 & \\
\hline 5. & $\begin{array}{l}\text { Removal } \\
\text { from the } \\
\text { position held }\end{array}$ & 1 & 1 & 0 & 1 & 0 & 1 & 0 & 1 & 0 & 0 & 5 \\
\hline 6. & $\begin{array}{l}\text { Transfer } \\
\text { to another } \\
\text { place of } \\
\text { work }\end{array}$ & 1 & 4 & 2 & 3 & 3 & 2 & 5 & 4 & 1 & 0 & 25 \\
\hline 7. & $\begin{array}{l}\text { Dismissal of } \\
\text { a judge from } \\
\text { the office / } \\
\text { Deprivation } \\
\text { of the right } \\
\text { to retirement }\end{array}$ & 0 & 1 & 1 & 3 & 4 & 1 & 4 & 3 & 1 & 2 & 20 \\
\hline 8. & $\begin{array}{c}\text { Waiver of } \\
\text { punishment }\end{array}$ & 7 & 6 & 5 & 1 & 3 & 12 & 3 & 3 & 0 & 5 & 41 \\
\hline 9. & No data & 0 & 0 & 0 & 0 & 0 & 0 & 0 & 0 & 0 & 3 & 3 \\
\hline & Total* & 27 & 25 & 20 & 24 & 39 & 45 & 35 & 27 & 5 & 14 & - \\
\hline
\end{tabular}

* The total number of cases is not always consistent with the number of cases in a given year or the number of acts committed, and depends on the content of the sentence of rulings issued in individual cases. The court usually imposed a total penalty for two or more disciplinary offenses. 
Table 6. Types of judgments - the Supreme Court's ruling as a court of the second instance

\begin{tabular}{|c|c|c|c|c|c|c|c|c|c|c|c|c|}
\hline \multirow[b]{2}{*}{ No. } & \multirow{2}{*}{$\begin{array}{c}\text { Type of } \\
\text { judgment }\end{array}$} & \multicolumn{10}{|c|}{ Number of cases } & \multirow[b]{2}{*}{ Total } \\
\hline & & 록 & $\overline{\bar{\nu}}$ & בิ้ & $\stackrel{\text { ก }}{\overline{2}}$ & 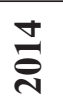 & $\frac{\pi}{2}$ & 률 & 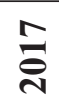 & $\stackrel{\infty}{\frac{\pi}{2}}$ & 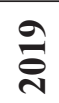 & \\
\hline 1. & $\begin{array}{l}\text { Upholding the } \\
\text { previous ruling }\end{array}$ & 19 & 16 & 10 & 9 & 27 & 26 & 25 & 19 & 2 & 5 & 158 \\
\hline 2. & $\begin{array}{c}\text { Change and } \\
\text { acquittal }\end{array}$ & 3 & 2 & 0 & 1 & 6 & 3 & 3 & 1 & 0 & 0 & 19 \\
\hline 3 & $\begin{array}{l}\text { Change and } \\
\text { conviction }\end{array}$ & 1 & 0 & 0 & 1 & 0 & 0 & 0 & 0 & 0 & 1 & 3 \\
\hline 4. & $\begin{array}{l}\text { Change and } \\
\text { a milder type } \\
\text { of penalty }\end{array}$ & 1 & 0 & 1 & 3 & 3 & 0 & 3 & 1 & 1 & 0 & 13 \\
\hline 5. & $\begin{array}{c}\text { Change and } \\
\text { a more severe } \\
\text { type of penalty }\end{array}$ & 3 & 4 & 4 & 4 & 1 & 5 & 5 & 5 & 1 & 2 & 34 \\
\hline 6. & $\begin{array}{c}\text { Change and } \\
\text { waiver of the } \\
\text { penalty }\end{array}$ & 0 & 1 & 0 & 0 & 1 & 0 & 0 & 0 & 0 & 1 & 3 \\
\hline 7. & $\begin{array}{c}\text { Setting aside } \\
\text { the judgment } \\
\text { and discon- } \\
\text { tinuation of the } \\
\text { proceedings }\end{array}$ & 1 & 5 & 2 & 2 & 2 & 6 & 3 & 0 & 0 & 1 & 21 \\
\hline 8. & $\begin{array}{c}\text { Setting aside } \\
\text { the judgment } \\
\text { and remanding } \\
\text { the case }\end{array}$ & 4 & 5 & 4 & 4 & 13 & 11 & 4 & 7 & 0 & 2 & 54 \\
\hline 9. & No data & 0 & 0 & 0 & 0 & 0 & 0 & 0 & 0 & 0 & 3 & 2 \\
\hline & Total* & 32 & 33 & 21 & 24 & 53 & 51 & 43 & 33 & 4 & 15 & - \\
\hline
\end{tabular}

* The total number of cases is not always consistent with the number of cases in a given year or the number of acts committed and depends on the content of the sentence of rulings issued in individual cases. 
The data contained in Tables 5 and 6 show that the Supreme Court usually upheld the rulings of the first instance disciplinary court. Changes to the decisions of the court of the first instance usually concerned a more severe penalty. Occasionally, there were cases of setting aside the judgment and discontinuing the proceedings, changing the judgment and waiving the penalty. Approximately one-third of the first-instance court rulings were set aside, and the case remanded. These situations are perfectly illustrated by examples 10-16 below.

\section{Example 10}

The judge, who also served as an inspector, was accused during disciplinary proceedings of committing the act of distorting of the content of the report from a hearing. In the first instance, the disciplinary court issued a warning. The Supreme Court changed the judgment under appeal and ordered the accused to be removed from the function of inspector. The Supreme Court decided that a person acting as an inspector should constitute an impeccable model of conduct for other judges. The accused, in the court's assessment, was not such a model. ${ }^{46}$

\section{Example 11}

The judge was blamed for announcing in the presence of the parties a decision to adjourn the hearing and a decision to appoint an expert, whereas after the persons attending had left the room, he ordered the clerk to change the content of the report from the hearing. The record regarding the adjournment of the hearing and the appointment of an expert were removed from the report. In their place, the decision to close the case and to declare the ruling was entered. This act was at the same time an offense. The disciplinary court of the first instance ordered the judge to be transferred to another place of service. The Supreme Court changed this judgment by imposing a penalty on the removal of the judge from office. The Supreme Court pointed out that the seriousness of the offense committed 
was very high. With his behaviour, the accused undermined the claim that he was qualified to hold the office of a judge. The only possible disciplinary penalty for this offense is the penalty of dismissing a judge from the office. ${ }^{47}$

\section{Example 12}

A retired judge was accused of driving a car under the influence of alcohol. The court of the first instance found the judge guilty of this act and ordered a suspension of salary increase for a period of 3 years. The Supreme Court ruled that the first instance court had imposed a grossly mild punishment. The conduct of the accused indicated a disregard for the legal order. Which, in turn, implies that he had thereby lost his qualification for the office of a judge, regardless of his previous service. Therefore, the judge deserved the most severe punishment. ${ }^{48}$

\section{Example 13}

The judge was accused of unknowingly taking a purse from a room at the headquarters of the District Chamber of Legal Advisers. After realizing the mistake, the judge did not return the purse to the owner but abandoned it at an unspecified place. The judge denied the whole incident. This behaviour made it impossible to find the purse. The court of the first instance imposed a reprimand on the judge. The Supreme Court held that the judge's behaviour could not be reconciled with the impeccable character required of a judge. The judge should be guided by the principles of honesty, a sense of honour and good manners. The conduct of the accused violated these principles. An adequate penalty for the offense would be transfer to another place of service. ${ }^{49}$

\section{Example 14}

The judge was accused of allowing the parties to settle when the circumstances of the case showed that the act was unlawful and intended 
to circumvent the law. By his behaviour, the judge created the danger of hindering the pursuit of claims by creditor entities. For this offense, the first instance court ordered the judge to be removed from office. The Supreme Court found that the sentence imposed was grossly severe. The Supreme Court had in mind the behaviour of the accused after committing the offense aimed at setting aside the effects of the offense and her earlier service. In the opinion of the Supreme Court, an adequate penalty was the transfer to another place of service. ${ }^{50}$

\section{Example 15}

The judge was accused of taking the incorrect procedural decision, without legal and factual grounds, of excluding the case for a separate examination of the main thread of the case. This decision led to lengthy proceedings. The disciplinary court of the first instance found that there had been a violation of the rules of procedure and imposed a warning. The Supreme Court, as a court of the second instance, recognized that the disciplinary court's decision had entered the sphere of the judge's independence. A judge who would be concerned by the threat of disciplinary responsibility when issuing a judgment could not be independent. The Supreme Court found that the accused's decision was of a procedural nature and involved a decision-making process. In the court's view, the judge could not be held to have committed an act of offense against the law, and therefore acquitted the accused..$^{51}$

\section{Example 16}

The judge was found guilty, by the disciplinary court of the first instance, of having violated the dignity of her profession by obstructing her exhusband's contact with their child. In this way, the judge did not respect the court's judgment establishing the rules of contact between the father and the minor. The accused was punished with a reprimand. In the opin- 
ion of the Supreme Court, this penalty was grossly severe. The Supreme Court took into consideration in favour of the accused her reputation for impeccable service and family situation, and imposed a warning. ${ }^{52}$

The examples described above show that the Supreme Court corrected cases both of too mild treatment of the accused by the court of the first instance and situations of too harsh assessment of the behaviour of the accused.

\section{Offenses Committed by Judges}

According to data provided by the Ministry of Justice, from October 1, 2001 to September 2018, the Minister of Justice was notified of the issuance of 107 resolutions of the Supreme Court authorizing the prosecution of judges. ${ }^{53}$ The list of acts the judges were accused of is provided in Table 7.

Table 7. List of crimes alleged against judges in the years 2001-2018

\begin{tabular}{|c|c|c|c|}
\hline No. & \multicolumn{2}{|c|}{ Type of crime } & $\begin{array}{c}\text { Article } \\
\text { number }\end{array}$ \\
\hline 1. & $\begin{array}{c}\text { Offenses } \\
\text { against life and } \\
\text { health }\end{array}$ & $\begin{array}{c}\text { Causing a violation of body organ func- } \\
\text { tioning or causing a health disorder lasting } \\
\text { up to 7 days and over 7 days }\end{array}$ & $\begin{array}{c}\text { art. 157 } \\
\S 1 \text { and } 2 \\
\text { PC1* }\end{array}$ \\
\hline \multirow{2}{*}{2.} & $\begin{array}{c}\text { Offenses } \\
\text { against se- } \\
\text { curity in } \\
\text { communication }\end{array}$ & $\begin{array}{c}\text { Causing a traffic accident, including fatal } \\
\text { or serious damage to health }\end{array}$ & $\begin{array}{c}\text { art. 177 } \\
\S 1 \text { and 2 } \\
\text { PC }\end{array}$ \\
\cline { 2 - 4 } 3. & $\begin{array}{c}\text { Driving under the influence of alcohol or } \\
\text { drugs }\end{array}$ & $\begin{array}{c}\text { art. 178a } \\
\S 1 \text { and 2 } \\
\text { PC }\end{array}$ \\
\hline & $\begin{array}{c}\text { Offenses } \\
\text { against } \\
\text { freedom }\end{array}$ & Violent or unlawful threat against a person & $\begin{array}{c}\text { art. 191 } \\
\S 1 \mathrm{PC}\end{array}$ \\
\hline
\end{tabular}

52 SNO 39/13.

53 See Ł. Piebiak, Odpowiedź na interpelację nr 25389... 
The Disciplinary and Criminal Liability of Judges in Poland... | 313

\begin{tabular}{|c|c|c|c|}
\hline No. & & Type of crime & $\begin{array}{l}\text { Article } \\
\text { number }\end{array}$ \\
\hline \multirow{4}{*}{4.} & \multirow{4}{*}{$\begin{array}{l}\text { Offenses } \\
\text { against sexual } \\
\text { freedom and } \\
\text { decency }\end{array}$} & $\begin{array}{l}\text { Rape and leading another person to un- } \\
\text { dergo another sexual activity }\end{array}$ & $\begin{array}{l}\text { art. } 197 \S 1 \\
\text { and } 2 \mathrm{PC}\end{array}$ \\
\hline & & $\begin{array}{l}\text { Abusing of dependency relationship or us- } \\
\text { ing of critical position and causing another } \\
\text { person to have sexual intercourse or other } \\
\text { sexual activity }\end{array}$ & $\begin{array}{l}\text { art. } 199 \\
\S 1 \mathrm{PC}\end{array}$ \\
\hline & & $\begin{array}{l}\text { Sexual intercourse with a minor under the } \\
\text { age of } 15 \text { years }\end{array}$ & $\begin{array}{l}\text { art. } 200 \\
\S 1 \mathrm{PC}\end{array}$ \\
\hline & & Incest & $\begin{array}{l}\text { art. } 201 \\
\text { PC }\end{array}$ \\
\hline 5. & $\begin{array}{l}\text { Offenses } \\
\text { against family } \\
\text { and care }\end{array}$ & $\begin{array}{l}\text { Physical or psychological harassment of } \\
\text { the closest person or another person being } \\
\text { in a constant or transient relationship with } \\
\text { the perpetrator }\end{array}$ & $\begin{array}{l}\text { art. } 207 \\
\S 1 \mathrm{PC}\end{array}$ \\
\hline 6. & $\begin{array}{l}\text { Offenses } \\
\text { against honour } \\
\text { and bodily } \\
\text { integrity }\end{array}$ & $\begin{array}{c}\text { Defamation of another person by means of } \\
\text { mass communication }\end{array}$ & $\begin{array}{l}\text { art. } 212 \\
\S 2 \mathrm{PC}\end{array}$ \\
\hline \multirow{5}{*}{7.} & \multirow{5}{*}{$\begin{array}{l}\text { Offenses } \\
\text { against the } \\
\text { activity of } \\
\text { state institu- } \\
\text { tions and local } \\
\text { government }\end{array}$} & $\begin{array}{c}\text { Violation of bodily integrity of a public } \\
\text { official }\end{array}$ & $\begin{array}{l}\text { art. } 222 \\
\S 1 \mathrm{PC}\end{array}$ \\
\hline & & Insulting a public official & $\begin{array}{l}\text { art. } 226 \\
\S 1 \mathrm{PC} \\
\end{array}$ \\
\hline & & $\begin{array}{l}\text { Dependence of the performance of official } \\
\text { activity on the receipt of financial or per- } \\
\text { sonal benefits, including for conduct that } \\
\text { constitutes a violation of the law }\end{array}$ & $\begin{array}{l}\text { art. } 228 \\
\S 1 \text { and } 3 \\
\text { PC }\end{array}$ \\
\hline & & $\begin{array}{l}\text { Execution of official duties subject to re- } \\
\text { ceipt of financial or personal benefits }\end{array}$ & $\begin{array}{l}\text { art. } 228 \\
\S 4 \mathrm{PC}\end{array}$ \\
\hline & & $\begin{array}{l}\text { Acceptance of a financial advantage of } \\
\text { considerable value in connection with per- } \\
\text { forming a public function }\end{array}$ & $\begin{array}{l}\text { art. } 228 \\
\S 5 \mathrm{PC}\end{array}$ \\
\hline
\end{tabular}




\begin{tabular}{|c|c|c|c|}
\hline No. & & Type of crime & $\begin{array}{l}\text { Article } \\
\text { number }\end{array}$ \\
\hline \multirow{5}{*}{7.} & \multirow{5}{*}{$\begin{array}{c}\text { Offenses } \\
\text { against the } \\
\text { activity of } \\
\text { state institu- } \\
\text { tions and local } \\
\text { government }\end{array}$} & $\begin{array}{l}\text { Mediation in settling the matter in ex- } \\
\text { change for financial or personal benefit }\end{array}$ & $\begin{array}{l}\text { art. } 230 \\
\S 1 \mathrm{PC}\end{array}$ \\
\hline & & $\begin{array}{c}\text { Abuse of rights in connection with the per- } \\
\text { formance of a public function }\end{array}$ & $\begin{array}{l}\text { art. } 231 \\
\S 1 \mathrm{PC}\end{array}$ \\
\hline & & $\begin{array}{c}\text { Making false testimonies in court proceed- } \\
\text { ings or other proceedings conducted pursu- } \\
\text { ant to the Act }\end{array}$ & $\begin{array}{l}\text { art. } 233 \\
\S 1 \text { and } 6 \\
\text { PC }\end{array}$ \\
\hline & & $\begin{array}{c}\text { False accusation of another person of } \\
\text { committing a criminal act or disciplinary } \\
\text { offense }\end{array}$ & $\begin{array}{l}\text { art. } 234 \\
\text { PC }\end{array}$ \\
\hline & & False crime notification & $\begin{array}{l}\text { art. } 238 \\
\text { PC }\end{array}$ \\
\hline 9. & $\begin{array}{l}\text { Offenses } \\
\text { against elec- } \\
\text { tions and } \\
\text { referendum }\end{array}$ & Infringement during the election & $\begin{array}{l}\text { art. } 248 \\
\text { PC }\end{array}$ \\
\hline 10. & $\begin{array}{l}\text { Offenses } \\
\text { against public } \\
\text { order }\end{array}$ & $\begin{array}{l}\text { Participation in an organized criminal } \\
\text { group }\end{array}$ & $\begin{array}{l}\text { art. } 258 \\
\S 1 \mathrm{PC}\end{array}$ \\
\hline \multirow{3}{*}{11.} & \multirow{3}{*}{$\begin{array}{l}\text { Offenses } \\
\text { against the } \\
\text { credibility of } \\
\text { documents }\end{array}$} & $\begin{array}{l}\text { Counterfeit or forged document and using } \\
\text { it as an authentic one }\end{array}$ & $\begin{array}{l}\text { art. } 270 \\
\S 1 \mathrm{PC}\end{array}$ \\
\hline & & $\begin{array}{l}\text { Certification of an untruth in a document } \\
\text { by a public official }\end{array}$ & $\begin{array}{l}\text { art. } 271 \\
\S 1 \mathrm{PC}\end{array}$ \\
\hline & & $\begin{array}{c}\text { Phishing a false statement by deceitfully } \\
\text { misleading a public official }\end{array}$ & $\begin{array}{l}\text { art. } 272 \\
\text { PC }\end{array}$ \\
\hline 12. & $\begin{array}{l}\text { Offenses } \\
\text { against } \\
\text { property }\end{array}$ & Theft and usurpation & $\begin{array}{c}\text { art. } 278 \\
\S 1 \text { and } \\
284 \S 1 \mathrm{PC}\end{array}$ \\
\hline
\end{tabular}

*Act of June 6, 1997 Penal Code (Journal of Law of 2019, item 1950). 
As is evident from the data contained in Table 7, judges were accused of committing crimes related to the office (e.g. paid protection) as well as those from the sphere of personal life (e.g. crimes against sexual freedom). It should be noted that Table 7 contains only data on the offenses in relation to which preparatory proceedings were pending against judges. The Ministry of Justice did not disclose data on convictions for individual offenses.

In March 2016, an Internal Affairs Department was created in the Internal Prosecutor's Office. The purpose of this department is to conduct preparatory proceedings in cases of the most serious crimes committed by judges, among others. In this department, seven indictments were brought against judges. By 2018, one of these proceedings in court had been discontinued in connection with the reconciliation of the parties. ${ }^{54}$

\section{Conclusions}

1. During the period analysed, the largest number of disciplinary cases per year heard by the disciplinary court was in the year 2007, while the smallest number of cases was in the year 2018. Poland is a country in which the number of disciplinary proceedings initiated is in the European average.

2. If there is an indictment against the accused, disciplinary proceedings usually end with the conviction of the accused in the first instance. The second instance court usually upholds the contested ruling, although in one third of the cases the case is referred back to the court.

3. The most common penalty imposed on the accused is a warning or a reprimand. These are the mildest penalties. The disciplinary court does not, however, avoid imposing the most severe penalties, i.e. transfer to another place of service or dismissal of a judge from office.

4. The most frequently occurring disciplinary offenses of judges were an obvious and blatant disregard for the law related to a failure to 
comply with the provisions on the speed and efficiency of proceedings as well as deadlines for preparing justifications for sentences.

5. The Supreme Court altered the penalties of a warning or a reprimand, respectively, to the transfer to another place of service or removal of a judge from the office, as well as the penalty of the removal of a judge from the office to transfer to another place of service. In this case, the gravity of the offense and its significance from the point of view of the good of the justice were taken into consideration, as well as the judge's previous service.

6. From October 1, 2001 to September 2018, 107 resolutions of the Supreme Court authorizing the prosecution of a judge occurred. The judges were accused of committing crimes both regarding the sphere of their profession (e.g. corruption) and closely related to their private lives (e.g. rape or driving a car in a state of intoxication).

7. Considering the results of the research, it would be worth conducting similar research in relation to other legal professions as well as undertaking a broader substantive discussion in this respect.

\section{References}

About the European Commission for the efficiency of justice (CEPEJ), $<$ https://www.coe.int/en/web/cepej/about-cepej>.

Acquaviva N., Castagnet F., Evanghelou M., A comparative analysis of Disciplinary Systems for European judges and prosecutors, For the 7th edition of the THEMIS Competition - 2012, <http://www.ejtn.eu/ Documents/Themis\%202012/THEMIS\%202012\%20ERFURT\%20 DOCUMENT/Written\%20paper\%20France\%203.pdf>.

Act of 20 December 2019 amending the Act - Law on the structure of common courts, the Act on the Supreme Court and some other acts (Journal of Laws of 2020, item 190). 
Act of 27 July 2001 Law on the System of Common Courts (Journal of Laws of 2020, item 365).

Act of June 6, 1997 Penal Code (Journal of Laws of 2019, item 1950).

CEPEJ Report on European judicial systems -Edition 2014 (2012 data): efficiency and quality of justice, <http://www.just.ro/wp-content/uploads/2015/09/editia-2014-en.pdf>.

CEPEJ Report on European judicial systems -Edition 2014 (2012 data): efficiency and quality of justice, <http://www.just.ro/wp-content/uploads/2015/09/editia-2014-en.pdf>.

Chudy K., Czy istnieje potrzeba wprowadzenia radykalnych zmian w sqdownictwie dyscyplinarnym zawodów prawniczych?, "Palestra” 2006, no. 5-6.

Constitution of the Republic of Poland of April 2, 1997 (Journal of Laws of 1997, no. 07, item 15).

Czarnecki P., Postępowanie dyscyplinarne wobec osób wykonujqcych prawnicze zawody zaufania publicznego, Warszawa 2013.

Ereciński T., Gudowski J., Iwulski J., Prawo o ustroju sq̨ów powszechnych. Ustawa o Krajowej Radzie Sądownictwa. Komentarz, Warszawa 2010.

Giętkowski R., Odpowiedzialność dyscyplinarna w prawie polskim, Gdańsk 2013. Gruodytè E., The disciplinary liability of Lithuanian Lawyers: a comparative approach, "Baltic Journal of Law \& Politics” 2014, no. 2.

Haley J. O., The Civil, Criminal and Disciplinary Liability of Judges, “The American Journal of Comparative Law” 2006, vol. 54.

Korzeniowska-Lasota A., Lasota M., Odpowiedzialność sędziego za wykroczenia, "Studia Prawnoustrojowe” UWM, 2010, no. 1.

Kozielewicz W., Odpowiedzialność dyscyplinarna sędziego za wykroczenie, in: Państwo prawa i prawo karne. Księga jubileuszowa Profesora Andrzeja Zolla, ed. P. Kardas, vol. 2, Lex.

Kozielewicz W., Odpowiedzialność dyscyplinarna sędziów, in: Odpowiedzialność dyscyplinarna sędziów, prokuratorów, radców prawnych i notariuszy, ed. W. Kozielewicz, Warszawa 2016. 
Lista sq̨dów powszechnych, <https://dane.gov.pl/dataset/985,lista-sadow -powszechnych/resource/3873/table?page=3\&per_page=20\&q=\&sort=>. Minimum Judicial Standards V, Disciplinary proceedings and liability of judges, ENCJ Report 2014-2015, <https://www.encj.eu/images/stories/pdf/GA/ Hague/encj_report_minimum_standards_v_adopted_ga_june_2015.pdf $>$. Paśnik J., Prawo dyscyplinarne w Polsce, Warszawa 2000.

Piebiak Ł., Odpowiedź na interpelację nr 25389 w sprawie postępowań karnych wobec sędziów, <http://www.sejm.gov.pl/sejm8.nsf/InterpelacjaTresc.xsp?key=B4SHUE $>$.

Resolution No. 25/2017 of The National Council of the Judiciary of January 13, 2017 regarding the publication of a consolidated text of the Set of Professional Ethics Rules for Judges and Court Assessors, <https:// krs.pl/pl/o-radzie/zbior-zasad-etyki-zawodowej-sedziow/591-uchwala-nr-25-2017-krajowej-rady-sadownictwa-z-dnia-13-stycznia2017-r.html>.

Sawiński J., Commentary on Article 107 LSCC, in: Law on the structure of common courts. Commentary, ed. A. Górski, Lex 2013.

Supreme Court ruling reference number SNO 16/15 (April 14, 2015). Supreme Court ruling reference number SNO 21/16 (June 16, 2016). Supreme Court ruling reference number SNO 23/14 (June 5, 2014). Supreme Court ruling reference number SNO 23/17 (July 19, 2017). Supreme Court ruling reference number SNO 24/14 (June 5, 2014). Supreme Court ruling reference number SNO 26/2016 (May 2, 2020). Supreme Court ruling reference number SNO 29/12 (June 29, 2012). Supreme Court ruling reference number SNO 30/12 (June 21, 2012). Supreme Court ruling reference number SNO 31/11 (July 20, 2011). Supreme Court ruling reference number SNO 31/16 (September 26, 2016). Supreme Court ruling reference number SNO 34/14 (July 18, 2014). Supreme Court ruling reference number SNO 34/15 (June 22, 2015). Supreme Court ruling reference number SNO 36/12 (January 15, 2013). Supreme Court ruling reference number SNO 39/13 (January 22, 2014). Supreme Court ruling reference number SNO 40/13 (January 22, 2014). 
Supreme Court ruling reference number SNO 41/11 (October 28, 2011). Supreme Court ruling reference number SNO 45/15 (August 20, 2015). Supreme Court ruling reference number SNO 56/12 (January 31, 2013). Supreme Court ruling reference number SNO 59/15 (October 13, 2015). Supreme Court ruling reference number SNO 6/13 (April 18, 2013). Supreme Court ruling reference number SNO 60/14((December 11, 2014). Supreme Court ruling reference number SNO 65/15 (October 26, 2015). Supreme Court ruling reference number SNO 66/15 (October 26, 2015). Supreme Court ruling reference number SNO 7/16 (September 14, 2016). Supreme Court ruling reference number SNO 9/15 (March 20, 2015). Tsaoussi A., Zervogianni E., Judges as satisficers: a law and economics perspective on judicial liability, "European Journal of Law and Economics” 2010, no. 29.

\section{SUMMARY}

\section{The Disciplinary and Criminal Liability of Judges in Poland. A Criminalistics Study of Cases of Disciplinary and Criminal Liability of Judges in the Years 2010-2018}

The article presents basic findings about the disciplinary and criminal liability of common courts judges in Poland. These findings are presented from a criminalistics perspective. The article provides data on the following issues: the basics of the disciplinary and criminal liability of judges, the number of disciplinary cases of judges in the years 2010-2018 and the number of criminal cases of judges in the years 2001-2017, categories of the disciplinary violations and crimes committed, decisions taken in cases of disciplinary violations, and imposed penalties. The article is based on an examination of Supreme Court verdicts issued in disciplinary cases of judges and data provided by the Ministry of Justice

Keywords: disciplinary liability, criminal liability, judges, legal ethics. 
Małgorzata Hrehorowicz, Adam Mickiewicz University Poznań, Faculty of Law and Administration, Al. Niepodległości 53, 61-714 Poznań, Republic of Poland, e-mail: malgorzata.hrehorowicz@amu.edu.pl.

DOI 10.14746/ppuam.2020.11.15 